\title{
Histoplanimetrical Study on the Relationship between Invasion of Indigenous Bacteria into Intestinal Crypts and Proliferation of Epithelial Cells in Rat Ascending Colon
}

\author{
Youhei MANTANI ${ }^{1}$, Ei-ichirou TAKAHARA ${ }^{1)}$, Takashi TAKEUCHI ${ }^{2)}$, Junichi KAWANO ${ }^{3)}$, Toshifumi YOKOYAMA ${ }^{4)}$, \\ Nobuhiko $\mathrm{HOSHI}^{4)}$ and Hiroshi KITAGAWA ${ }^{1) *}$ \\ ${ }^{1)}$ Laboratory of Histophysiology, Department of Bioresource Science, Graduate School of Agricultural Science, Kobe University, 1-1 \\ Rokkodai-cho, Nada-ku, Kobe, Hyogo 657-8501, Japan \\ 2) Department of Veterinary Laboratory Animal Science, Faculty of Agriculture, Tottori University, 4-101 Koyama-cho Minami, Tottori, \\ Tottori 680-8553, Japan \\ ${ }^{3)}$ Laboratory of Microbiology and Immunology, Department of Bioresource Science, Graduate School of Agricultural Science, Kobe \\ University, 1-1 Rokkodai-cho, Nada-ku, Kobe, Hyogo 657-8501, Japan \\ ${ }^{4)}$ Laboratory of Molecular Functional Morphology, Department of Bioresource Science, Graduate School of Agricultural Science, Kobe \\ University, 1-1 Rokkodai-cho, Nada-ku, Kobe, Hyogo 657-8501, Japan
}

(Received 22 January 2013/Accepted 21 February 2013/Published online in J-STAGE 7 March 2013)

\begin{abstract}
The relationship between the invasion of indigenous bacteria into intestinal crypts and the proliferation of epithelial cells was histoplanimetrically investigated in the rat ascending colon. Indigenous bacteria preferentially adhered to the intestinal superficial epithelial cells in the mesenterium-attached mucosa (MAM) compared to those in the mesenterium-non-attached mucosa (MNM). Intestinal crypts with indigenous bacteria were also significantly more frequently found in MAM than in MNM. Total epithelial cells, columnar epithelial cells and goblet cells were significantly more abundant in the intestinal crypts with no-indigenous bacteria in MAM (MAM-C) than those in MNM (MNM-C), whereas the columnar epithelial cells were less abundant in MAM-C than in the intestinal crypts with indigenous bacteria in MAM (MAM-C-B). Columnar epithelial cells and goblet cells immuno-positive for proliferating cell nuclear antigen (PCNA) in MAM-C were more abundant than those in MNM-C, but less abundant than those in MAM-C-B. Toll-like receptor (TLR)-2, -4 and -9 were immuno-positive in the striated borders of the intestinal superficial epithelial cells, but their positive intensities were weaker in MAM than in MNM. From these findings, indigenous bacteria were confirmed to preferentially settle on the intestinal superficial epithelium of MAM in the rat ascending colon, and low TLRs-expression might contribute to the preferential settlement of indigenous bacteria in MAM. The increase of proliferating epithelial cells is probably induced by the invasion of indigenous bacteria into the intestinal crypts of MAM. KEY WORDS: ascending colon, epithelial proliferation, indigenous bacteria, rat, Toll-like receptor.
\end{abstract}

doi: 10.1292/jvms.13-0036; J. Vet. Med. Sci. 75(7): 939-947, 2013

A large number of indigenous bacteria settle in the animal alimentary tract. The bacterial settlement initiates immediately after birth by bacteria derived from mother, and the number and composition of indigenous bacteria are stable in the adult alimentary tract [4]. The number of indigenous bacteria in the chyme increases toward the caudal alimentary tract, that is, $0-10^{5}$ colony forming unit $(\mathrm{CFU}) / \mathrm{m} l$ in the stomach to jejunum, $10^{3}-10^{9} \mathrm{CFU} / \mathrm{m} l$ in the ileum and $10^{10}-10^{12} \mathrm{CFU} / \mathrm{m} l$ in the colon of human [28], resulting in total $2 \mathrm{~kg}$ of indigenous bacteria in the human alimentary tract [11]. From histoplanimetrical investigation along the longitudinal axis of the rat intestine, indigenous bacteria settle on the intestinal superficial epithelium, whose apical surface expresses special sugars throughout the large intestine, and indigenous bacteria also reside in the intestinal crypts in the cecum and proximal $30 \%$ of the colon $[34,35]$. Additionally, numerous indigenous bacteria exist between

\footnotetext{
*Correspondence To: Kitagawa, H., Laboratory of Histophysiology, Graduate School of Agricultural Science, Kobe University, 1-1 Rokkodai-cho, Nada-ku, Kobe, Hyogo 657-8501, Japan. e-mail: hkitagaw@kobe-u.ac.jp

(C)2013 The Japanese Society of Veterinary Science
}

the mucosal folds in the rat ascending colon [27]. However, the detailed distribution of the settlement sites of indigenous bacteria has not been investigated in the ascending colon.

The settlement of indigenous or exogenous bacteria is regulated by various host defense, such as digestive enzymes, bactericidal peptides, physical elimination of epithelial cells and so on $[7,14,15,17,37,38]$. In the previous studies, the secretions of lysozyme and secretory phospholipase A2 from Paneth cells [38] and the acceleration of epithelial cell migration [26] are induced in the local sites with bacterial hyper-proliferations in the rat ileum. From these findings, stable bacterial settlement is speculated to be maintained by the balance between the bacterial proliferation and the elimination of bacteria by host defense in the rat small intestine. On the other hand, the deceleration of epithelial cell migration might contribute to the reliable settlement of indigenous bacteria in the basal part of the mucosal folds in the rat ascending colon [27]. However, it has not been fully clarified how bacterial invasion into the intestinal crypts effects the epithelial cell kinetics in the rat ascending colon.

Toll-like receptors (TLRs) recognize bacterial constituents: TLR-2 recognizes peptidoglycan, lipoprotein, lipoteichoic acid and so on; TLR-4 recognizes lipopolysaccharides (LPS) from Gram-negative bacteria; and TLR-9 recognizes 
non-methylated $\mathrm{CpG}$ motifs abundantly contained in bacterial DNA $[1,12,24]$. Our previous studies hypothesize that the recognition of indigenous bacterial settlement and proliferation might be regulated by both membranous and soluble TLR-2 throughout the rat small intestine $[19,20]$. In the large intestine, TLRs-expressions have been studied using in vitro or molecular biological methods $[5,6,22,25,32,33]$. However, the TLRs-expression in the large intestine has not been clarified in vivo. Therefore, this study aims both to investigate the detailed distribution of the settlement and proliferation sites of indigenous bacteria and the change of epithelial cell proliferation due to the invasions of indigenous bacteria into the intestinal crypts, and also to discuss the functional significance of TLRs-expression in the rat ascending colon.

\section{MATERIALS AND METHODS}

Animals: Ten male Wistar rats aged 7 weeks (Japan SLC Inc., Hamamatsu, Japan) were maintained under conventional laboratory housing conditions. They were permitted free access to water and food (Lab MR Stock, Nosan Corp., Yokohama, Japan). The animal facility was maintained under conditions of a $12 \mathrm{hr}$ light/dark cycle at $23 \pm 1{ }^{\circ} \mathrm{C}$ and $50-60 \%$ humidity. Clinical and pathological examinations in all animals confirmed no signs of disorder. This experiment was approved by the Institutional Animal Care and Use Committee (Permission number: 22-05-01) and carried out according to the Kobe University Animal Experimentation Regulations.

Tissue preparation: After euthanasia with overdose peritoneal injection of pentobarbital sodium (Kyoritsu Seiyaku Corp., Tokyo, Japan), small tissue blocks were removed from the ascending colon of 10 rats, and all tissue blocks were immersion-fixed in $4 \%$ paraformaldehyde fixative ( $\mathrm{pH} 7.4)$ for $24 \mathrm{hr}$ at $4^{\circ} \mathrm{C}$ and then were snapfrozen in liquid nitrogen with reference to the embedding method described by Barthel and Raymond [3]. Four $\mu \mathrm{m}-$ thick sections were cut using a Coldtome HM505E (Carl Zeiss, Jena, Thüringen, Germany), placed on slide glasses precoated with $0.2 \% 3$-aminopropyltriethoxysilane (ShinEtsu Chemical Co., Tokyo, Japan) and stored at $-20^{\circ} \mathrm{C}$ until use.

Immunohistochemistry: Detection of antigens was conducted using the indirect method of enzyme immunohistochemistry. Briefly, after rinsing with $0.05 \%$ Tween-added $0.01 \mathrm{M}$ phosphate buffered saline (TPBS; $\mathrm{pH}$ 7.4), the sections for the detection of proliferating cell nuclear antigen (PCNA) were autoclaved for $20 \mathrm{~min}$ at $121^{\circ} \mathrm{C}$ for antigen retrieval. Then, all sections were immersed in absolute methanol and $0.5 \% \mathrm{H}_{2} \mathrm{O}_{2}$ for $30 \mathrm{~min}$, respectively. Three times TPBS rinse was performed after all preparation steps to remove any reagent residues. Following blocking with Blocking One Histo (Nacalai Tesque Inc., Kyoto, Japan) for $1 \mathrm{hr}$ at room temperature (r.t.), the sections were reacted with anti TLR-2 (D-17), -4 (M-16) or -9 (N-15) goat IgG (diluted at 1:100; Santa Cruz Biotechnology Inc., Santa Cruz, CA, U.S.A.) or anti PCNA (Ab-1) mouse $\operatorname{IgG}_{2 \mathrm{a}}$ (diluted at 1:100; Calbiochem, San Diego, CA, U.S.A.) for $18 \mathrm{hr}$ at $6^{\circ} \mathrm{C}$. The antibody specificity for rat TLR $-2,-4,-9$ or PCNA is described in the manufacturer's specification form (TLR2, sc-12504; TLR-4, sc-12511; TLR-9, sc-13215; PCNA, NA03), respectively. Then, the sections were incubated with horseradish peroxidase-conjugated anti goat $\mathrm{IgG}$ mouse IgG (AP186P) (diluted at 1:200; Chemicon International Inc., Billerica, MA, U.S.A.) or EnVisionTM/HRP (Dako Cytomation, Glostrup, Denmark) for $1 \mathrm{hr}$ at r.t. Finally, the sections were incubated with 3,3'-diaminobenzidine (Dojindo Lab., Mashiki, Kumamoto, Japan) containing $0.03 \% \mathrm{H}_{2} \mathrm{O}_{2}$, and were counterstained with hematoxylin. Control sections were incubated with TPBS, non-immunized goat IgG or non-immunized mouse $\operatorname{IgG}$ instead of the primary antibody.

Definition of tissue element: A section from each tissue block was stained with hematoxylin-eosin for observation of the general structures, with a focus on the settlement and proliferation of indigenous bacteria. From this observation, the mucosa of ascending colon was divided into two regions; the mesenterium-attached mucosa (MAM) and the mesenterium-non-attached mucosa (MNM) (Fig. 1). Furthermore, intestinal crypts were divided into the three types on the basis of a quantity of indigenous bacteria contained in the intestinal crypts; intestinal crypts which contained no indigenous bacteria, scarce indigenous bacteria and numerous indigenous bacteria. On the basis of these categories, the intestinal crypts were named MAM-C which contained no indigenous bacteria in MAM, MNM-C which contained no indigenous bacteria in MNM or MAM-C-B which contained numerous indigenous bacteria in MAM

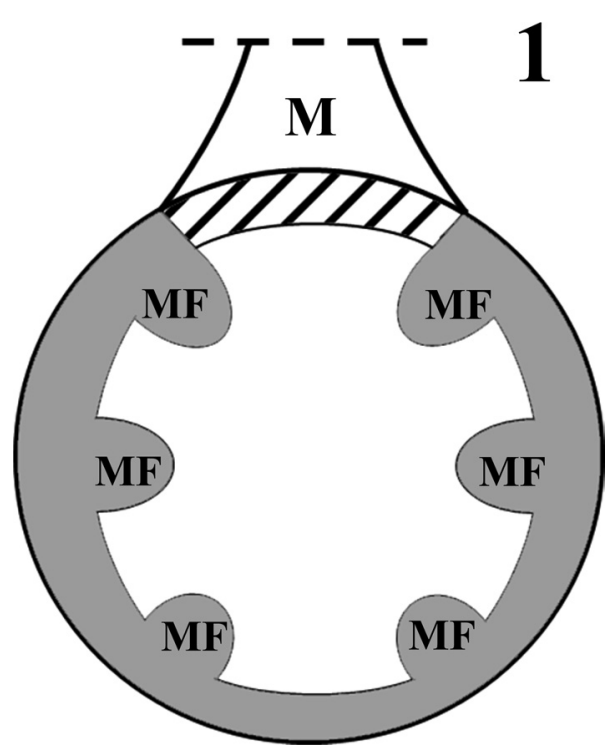

Fig. 1. Diagram of a transverse section of the rat ascending colon. The mesenterium-attached mucosa (MAM) is shown as a diagonal area, and the mesenterium-non-attached mucosa (MNM) is shown as a gray area. M, mesenterium. MF, mucosal fold. 
(Fig. 2). MNM-C-B could not be found, because the number of indigenous bacteria contained in the intestinal crypt was usually scarce in MNM.

Histoplanimetry: In this histoplanimetry, all intestinal crypts were chosen from the intestinal crypts between the mucosal folds and not from the intestinal crypts associated with the mucosal folds. Twenty intestinal crypts which were centrally cut along their longitudinal axes were randomly chosen from both MAM and MNM for each animal, respectively. The relative frequency of the intestinal crypts with indigenous bacteria in their lumina was calculated from 5 animals. Data are presented as means \pm standard deviations (SDs).

Ten MAM-C were randomly chosen from 5 rats which infrequently possessed the intestinal crypts filled with indigenous bacteria in their lumina, because MAM-C could not be sufficiently chosen from the other 5 rats whose intestinal crypts lumina were frequently filled with indigenous bacteria. Then, ten MNM-C were randomly chosen from the same 5 rats as an experimental control for MAM-C. Ten MAM-C-B were randomly chosen from the other 5 rats whose intestinal crypts lumina were frequently filled with indigenous bacteria. The depths of these MAM-C, MNM-C and MAM-C-B were measured, and mean depths were calculated from each 5 rats. Similarly, in each 5 MAM-C, MNM-C and MAM-C-B, the number of total epithelial cells, columnar epithelial cells and goblet cells was counted, and these mean numbers were calculated from 5 rats each. Following the definition of the crypt base as $0 \%$ and the crypt orifice as $100 \%$, the number of columnar epithelial cells and goblet cells were counted for each $10 \%$ segment of 5 MAM-C, MNM-C and MAM-C-B, and these means were calculated from 5 rats each. Additionally, in

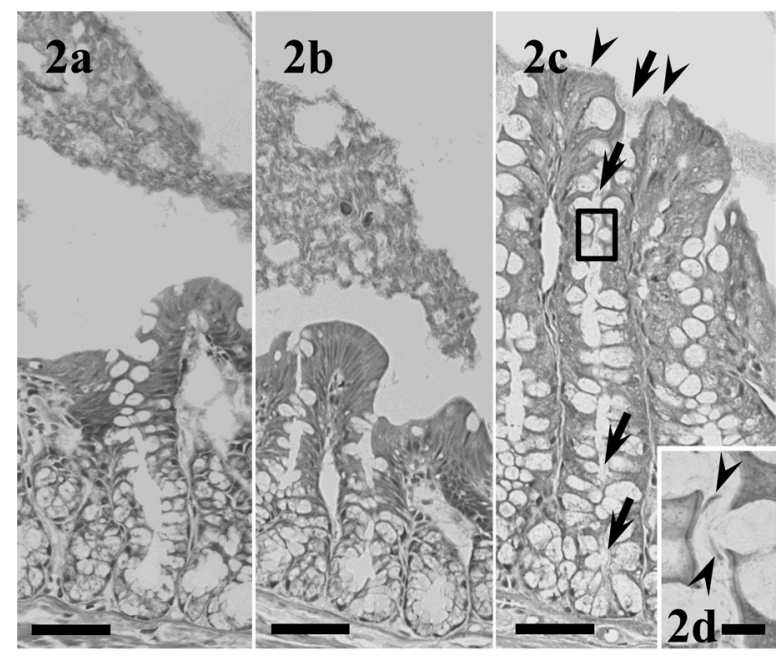

Fig. 2. Three types of intestinal crypts in the ascending colon: MAM-C (a), MNM-C (b) and MAM-C-B (c). d) High magnification photograph of lumina of MAM-C-B showed in (c). Indigenous bacteria are visible on the surfaces of intestinal superficial epithelial cells of MAM (c, arrowheads) and in the lumen of MAM-C-B (c, arrows; d, arrowheads), but not in the lumen of MAM-C (a) or MNM-C (b). a-c) Bar=50 $\mu \mathrm{m}, \mathrm{d}$ ) Bar=10 $\mu \mathrm{m}$.
5 MAM-C, MNM-C and MAM-C-B chosen from each 5 rats, the numbers of $\mathrm{PCNA}^{+}$total epithelial cells, columnar epithelial cells and goblet cells in MAM-C, MNM-C or MAM-C-B were counted, and the means were calculated. In 20 epithelial cells chosen from each $10 \%$ segment of MAM-C, MNM-C and MAM-C-B of each 5 rats, the relative frequencies of $\mathrm{PCNA}^{+}$columnar epithelial cells and goblet cells were calculated, and the means were calculated. The data were presented as means \pm SDs. Furthermore, in 5 MAM-C and MAM-C-B chosen from each 5 rats, the depths of MAM-C and MAM-C-B were measured, and the number of $\mathrm{PCNA}^{+}$epithelial cells was counted. The relationship between the depth of intestinal crypts and the number of total $\mathrm{PCNA}^{+}$epithelial cells was presented as a scatter diagram.

Statistical analysis: Pearson's correlation coefficient (r) was used to study the relationship between the depth of intestinal crypts and the number of total $\mathrm{PCNA}^{+}$epithelial cells. For other data, the normality of distribution was assessed by Shapiro-Wilk test, and statistical analysis was performed with Student's $t$ test for parametric variables and Mann-Whitney $U$ test for non-parametric variables. When necessary, the $t$ test was modified to all for unequal variance with Welch's test. All differences were assessed with the two-sided test, and $P$ values less than 0.05 were considered

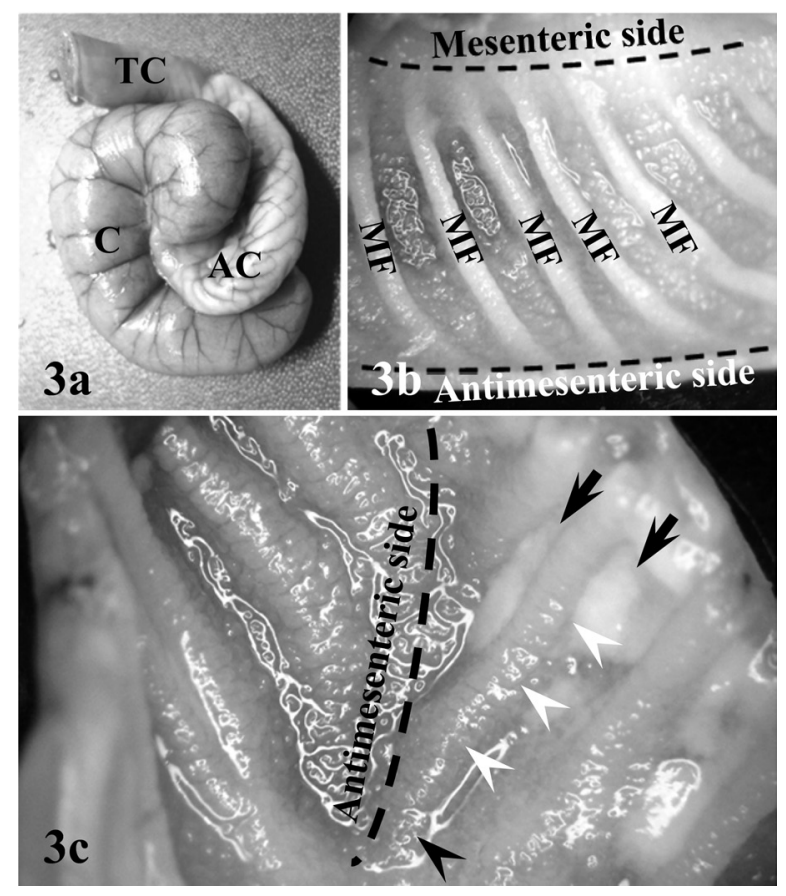

Fig. 3. The dorsal view of the large intestine from the cecum to the transverse colon (a), the inside view of ascending colon (b) and the inside view of antimesenteric side of ascending colon (c). Mucosal folds running obliquely exist from the mesenteric side toward the antimesenteric side (b), and the mucosal folds gradually shorten (c, white arrowheads) and are finally lost in the antimesenteric side (c, black arrowhead). White substances are visible between the mucosal folds (c, black arrows). C, cecum. AC, ascending colon. TC, transverse colon. MF, mucosal fold. 
statistically significant.

\section{RESULTS}

Macroscopic findings: The mucosal folds latero-caudally run from the mesenterium-attached site, shortened toward the antimesenteric side and finally disappear in the antimesenteric site in the rat ascending colon. Between the mucosal folds, white substances were found (Fig. 3).

General histology: The spaces between the mucosal folds were mainly filled with indigenous bacteria and extremely rarely contained food-derived substances. Indigenous bacteria preferentially adhered to the intestinal superficial epithelial cells of MAM compared to those of MNM. In the intestinal crypts which contained numerous indigenous bacteria, indigenous bacteria adhered to the intestinal superficial epithelial cells were connected with indigenous bacteria in the intestinal crypt lumen in MAM (Fig. 2). Intestinal crypts with indigenous bacteria were more frequently found in MAM than in MNM (Fig. 4).

Epithelial cell population in the intestinal crypt: The depth of MAM-C $(174 \pm 18.3 \mu \mathrm{m})$ was significantly higher than $120.8 \pm 5.7 \mu \mathrm{m}$ of MNM-C $(P<0.01)$ and lower than $230.5 \pm 15.2 \mu \mathrm{m}$ of MAM-C-B $(P<0.01)$. The numbers of total epithelial cells, columnar epithelial cells and goblet cells were significantly larger in MAM-C than in MNM-C. The numbers of total epithelial cells and columnar epithelial cells were significantly lower in MAM-C than in MAM-C-B, whereas the number of goblet cells was not different in the two types of intestinal crypts (Fig. 5). Columnar epithelial cells increased from the crypt base toward the crypt orifice, while goblet cells decreased from the crypt base toward the crypt orifice in MAM-C, MNM-C and MAM-C-B. Columnar epithelial cells and goblet cells were significantly more abundant in MAM-C than in MNM-C segments, except for the $0-10 \%$ and $50-60 \%$ segments (columnar epithelial cells) and the $40-80 \%$ segments (goblet cells). On the other hand, the number of columnar epithelial cells was significantly lower in MAM-C than in MAM-C-B in the $0-50 \%$ and 90-100\% segments, whereas the number of goblet cells was not significantly different at any segment (Fig. 6).

PCNA-immuno-positive epithelial cells in the intestinal crypt: $\mathrm{PCNA}^{+}$epithelial cells were consistently located from the middle to apical portions of MAM-C, MNM-C and MAM-C-B. On the other hand, $\mathrm{PCNA}^{+}$epithelial cells were often also located in the basal portions of MAM-C-B. Strongly PCNA-immuno-positive columnar epithelial cells were usually found only from the middle to apical portions of MAM-C and MNM-C, but often found in the basal portions of MAM-C-B. The numbers of total $\mathrm{PCNA}^{+}$epithelial cells, columnar epithelial cells and goblet cells in MAM-C were greater than those in MNM-C and less than those in MAM-C-B. A highly significant statistical positive correlation $(r=0.837)$ was found between the depth of intestinal crypts and the number of total $\mathrm{PCNA}^{+}$epithelial cells in MAM $(P<0.01)$ (Fig. 7). The relative frequency of $\mathrm{PCNA}^{+}$columnar epithelial cells in MAM-C and MNM-C was not significantly different, except for the $90-100 \%$

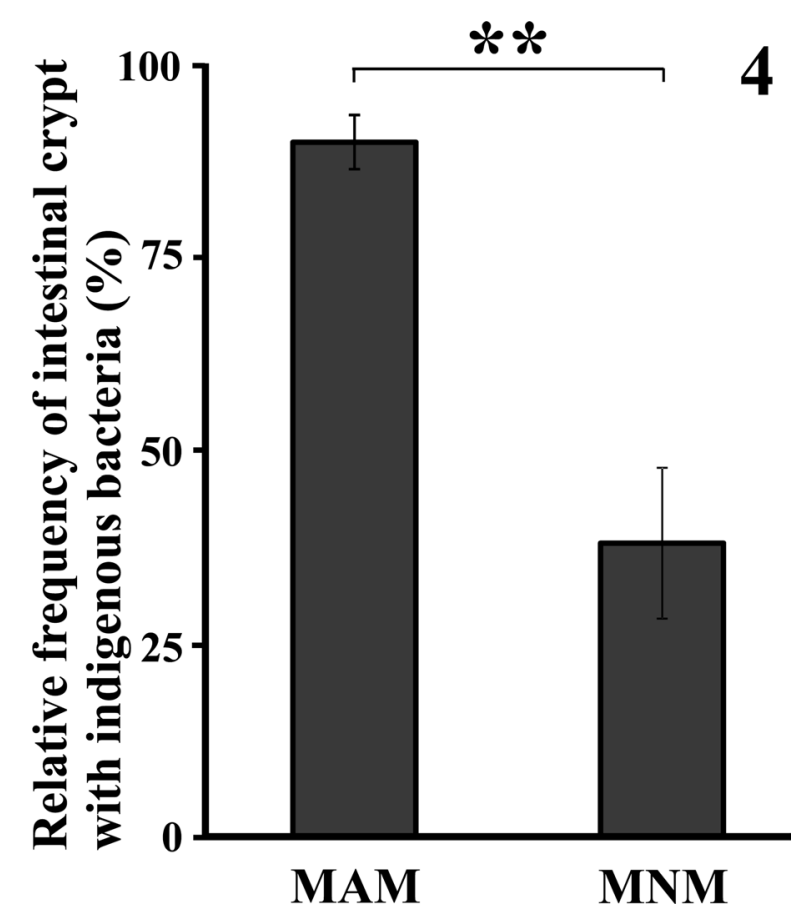

Fig. 4. Relative frequency of the intestinal crypts with indigenous bacteria in MAM and MNM. Double asterisk, $P<0.01$. Each value represents means \pm SDs.

segment, whereas the relative frequency of $\mathrm{PCNA}^{+}$ columnar epithelial cells in MAM-C was significantly lower than that in MAM-C-B in the $0-40 \%$ segments. On the other hand, $\mathrm{PCNA}^{+}$goblet cells were infrequent at any portion of MAM-C and MNM-C, and significantly less frequent in MAM-C than in MAM-C-B in the $0-20 \%$ and $40-50 \%$ segments. The most frequent sites of $\mathrm{PCNA}^{+}$columnar epithelial cells in the intestinal crypts were the 60-70\% segments of MAM-C, MNM-C and MAM-C-B (Fig. 8).

TLRs-localization in the mucosal epithelium: TLR-2, -4 and -9 were immuno-positive in the striated borders of intestinal superficial epithelial cells. These positive reactions were much weaker in MAM than in MNM (Fig. 9). TLR2, -4 and -9-immuno-positive vesicles were found in the cytoplasm of the intestinal superficial epithelial cells in MNM, but hardly found in MAM.

TLRs-immuno-positivities were not different among MAM-C, MNM-C and MAM-C-B. TLR-2, -4 and -9-immuno-positive reactions were weakly found in the secretory granules of goblet cells and the striated borders of columnar epithelial cells in the intestinal crypts. TLR-2 ${ }^{+}$ or $-4^{+}$goblet cells and columnar epithelial cells were rare, whereas TLR-9 $9^{+}$goblet cells and columnar epithelial cells were often found. TLRs ${ }^{+}$goblet cells were usually located in the intestinal crypt base.

\section{DISCUSSION}

In the rat ascending colon, numerous indigenous bacteria 


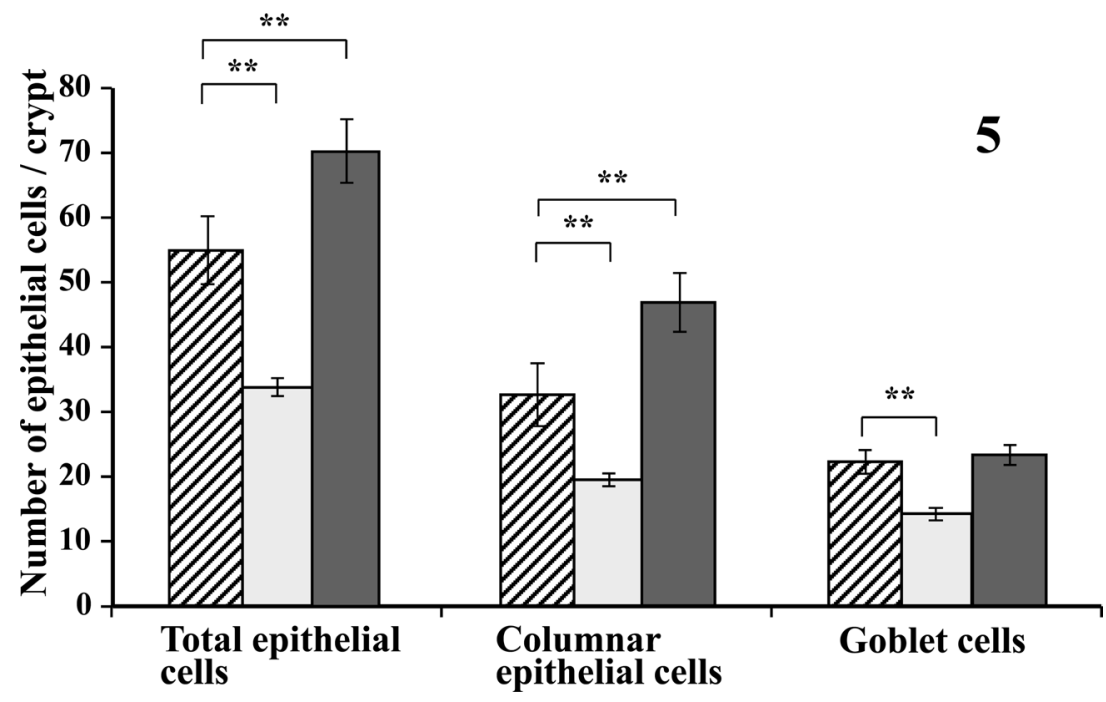

Fig. 5. The number of total epithelial cells, columnar epithelial cells and goblet cells in MAMC (diagonal columns), MNM-C (light gray columns) and MAM-C-B (dark gray columns). Double asterisks, $P<0.01$. Each value represents means \pm SDs.
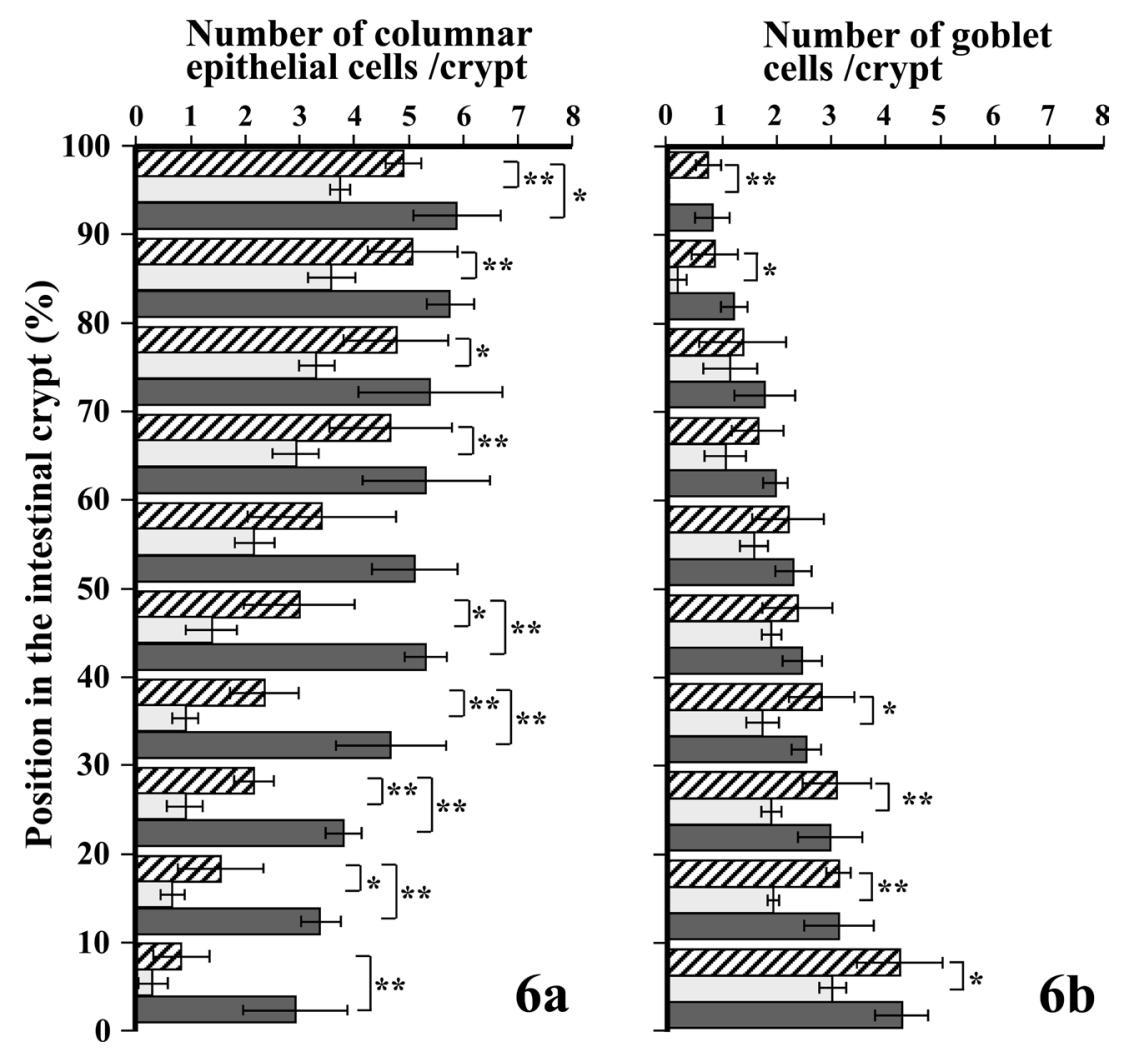

Fig. 6. The number of columnar epithelial cells (a) or goblet cells (b) in each $10 \%$ segment of MAM-C (diagonal columns), MNM-C (light gray columns) and MAM-C-B (dark gray columns). Asterisks, $P<0.05$. Double asterisks, $P<0.01$. Each value represents means \pm SDs. 

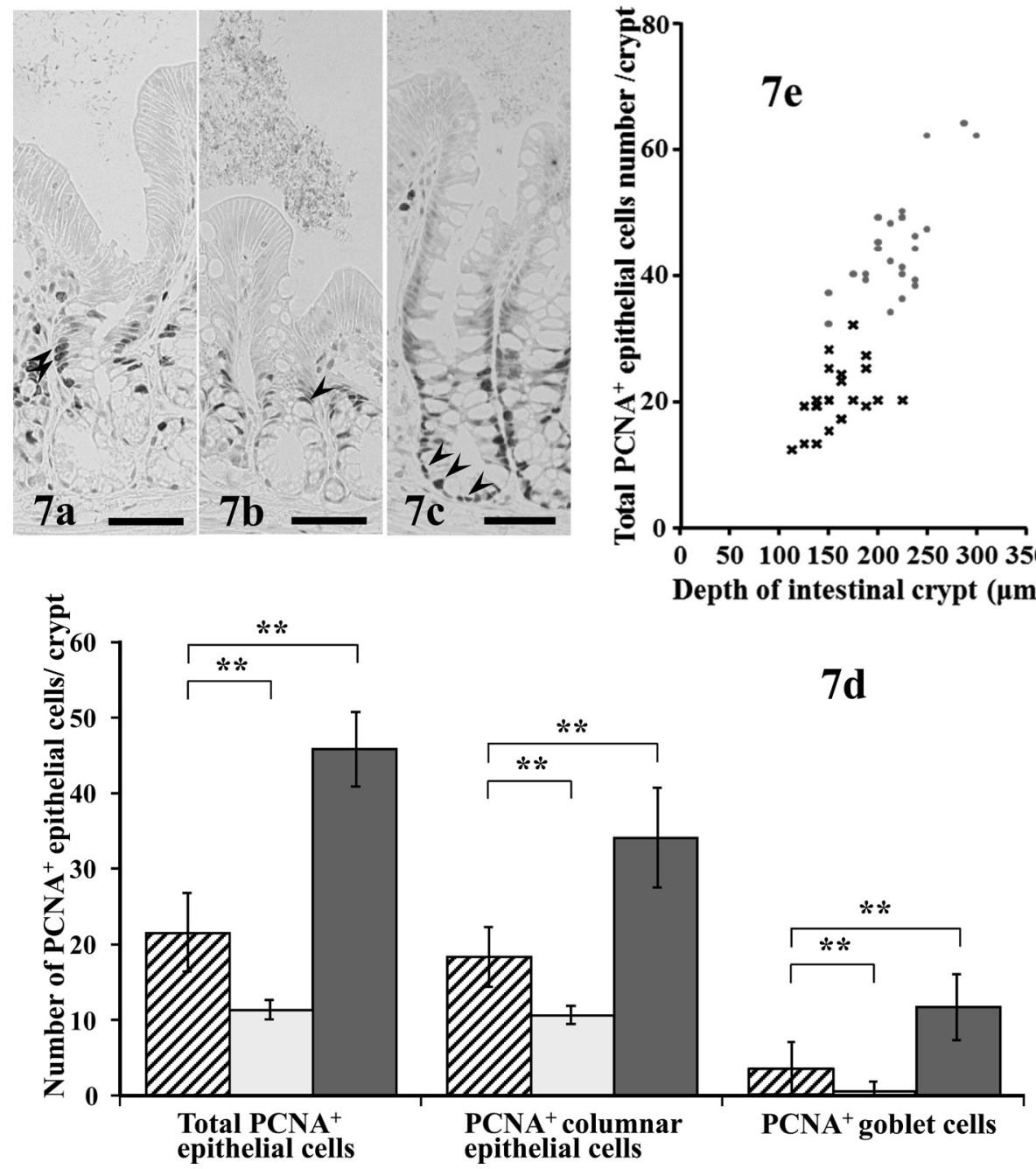

Fig. 7. Localization of PCNA in MAM-C (a), MNM-C (b) and MAM-C-B (c). In MAM-C (a) and MNM-C (b), $\mathrm{PCNA}^{+}$epithelial cells are located from the middle to apical portions, and the strongly immuno-positive reactions are visible in the epithelial cells of the middle portions (a, b, arrowheads). c) In MAM-C-B, PCNA ${ }^{+}$epithelial cells are located from the basal to apical portions, and the strongly immuno-positive reactions are also visible in the epithelial cells in the basal portions (arrowheads). $\mathrm{Bar}=50 \mu \mathrm{m}$. d) Number of total $\mathrm{PCNA}^{+}$epithelial cells, $\mathrm{PCNA}^{+}$columnar epithelial cells and $\mathrm{PCNA}^{+}$ goblet cells in MAM-C (diagonal columns), MNM-C (light gray columns) and MAM-C-B (dark gray columns). Double asterisks, $P<0.01$. Each value represents means \pm SDs. e) The relationship between the depth of intestinal crypt and total $\mathrm{PCNA}^{+}$epithelial cells in MAM-C (black cross marks) and MAM-C-B (gray circles). settle between the mucosal folds [27]. In the present study, white substances which were macroscopically found between the mucosal folds were microscopically confirmed to be the accumulations of almost all bacteria. From these findings, these white substances were suggested to be bacterial colonies, which settle between the mucosal folds.

In the previous study, settlement of indigenous bacteria on the mucosal surfaces in the intestine was investigated along the longitudinal axis of rat intestine using bacteriological and histological methods [34]. In the present study focusing on the differences of bacterial settlement in transverse sections of the rat ascending colon, indigenous bacteria more preferentially adhered to the intestinal superficial epithelial cells of MAM than to those of MNM. Furthermore, indigenous bacteria more frequently invaded the intestinal crypts of MAM than those of MNM. From these findings, indigenous bacteria were confirmed to preferentially settle on the intestinal superficial epithelium of MAM in the rat ascending colon. Furthermore, in the present study, immunopositivities of TLR-2, -4 and -9 were much weaker in the striated borders of intestinal superficial epithelial cells of MAM than in those of MNM. In the previous study, we 


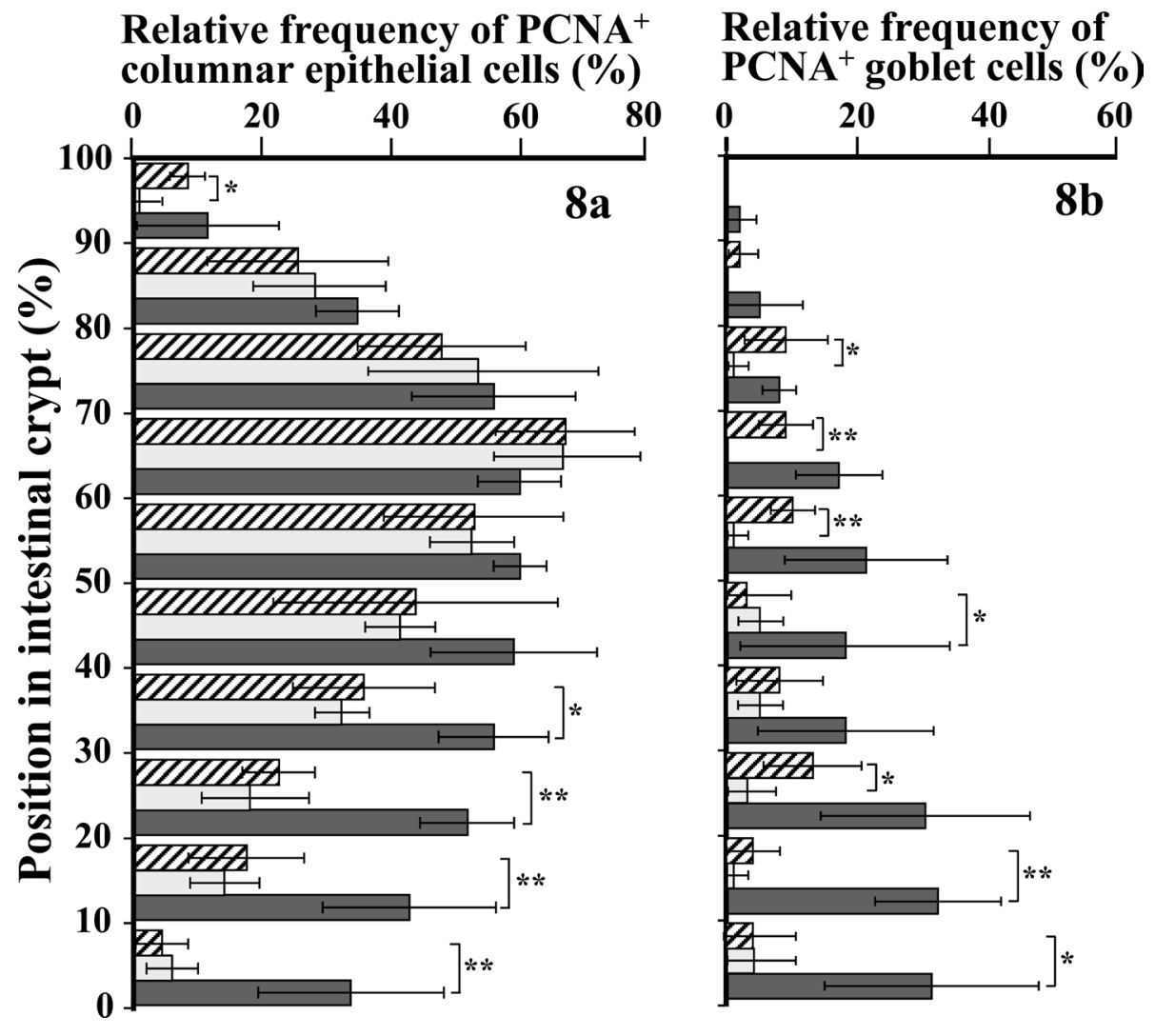

Fig. 8. Relative frequency of $\mathrm{PCNA}^{+}$columnar epithelial cells (a) or $\mathrm{PCNA}^{+}$goblet cells (b) in each $10 \%$ segment of MAM-C (diagonal columns), MNM-C (light gray columns) and MAM-C-B (dark gray columns). Asterisks, $P<0.05$. Double asterisks, $P<0.01$. Each value represents means $\pm \mathrm{SDs}$.

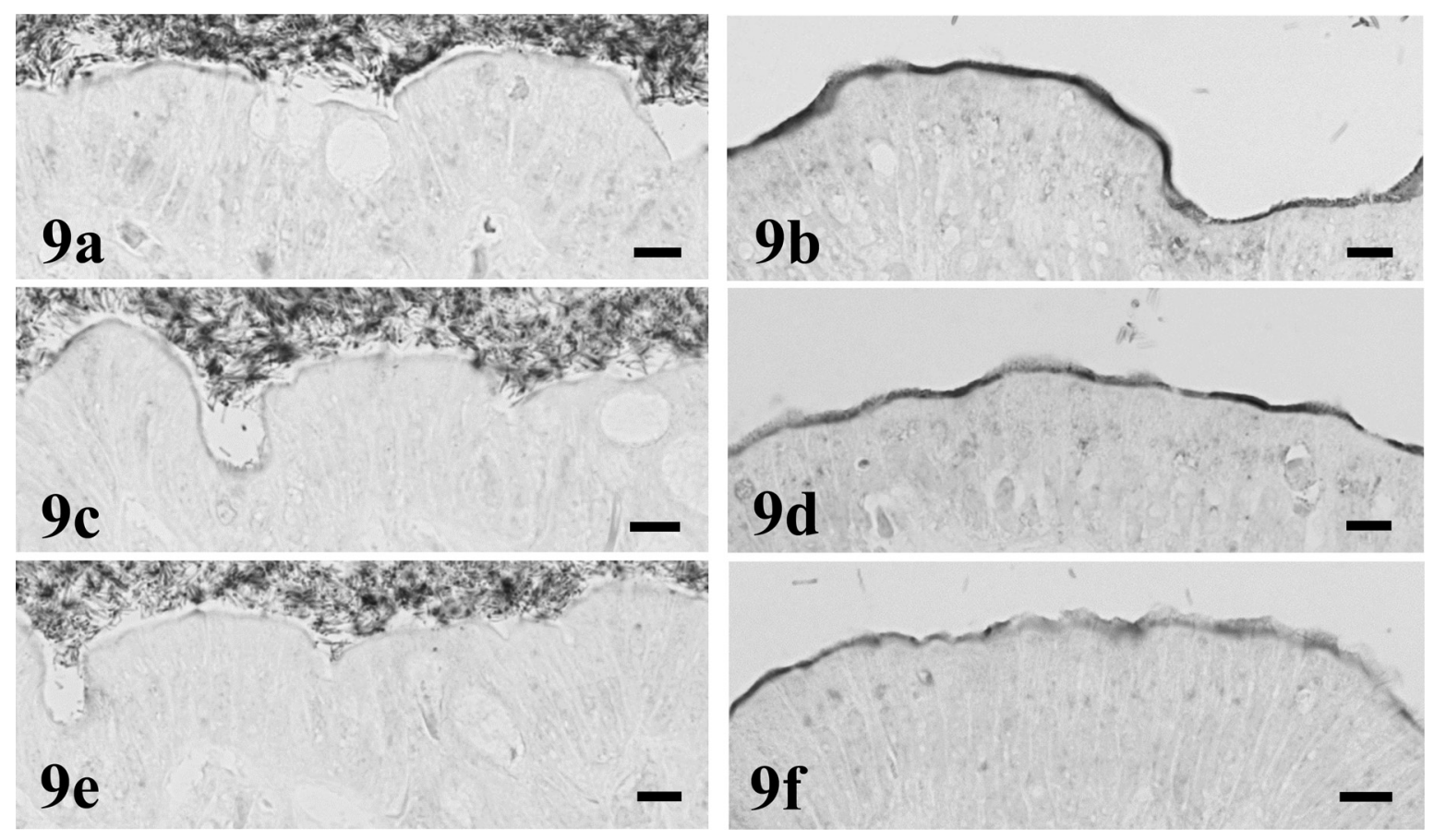

Fig. 9. Localization of TLR-2 (a, b), - 4 (c, d) and - $9(\mathrm{e}, \mathrm{f})$ in the intestinal superficial epithelial cells. Immuno-positivities of TLRs in the striated borders of intestinal superficial epithelial cells are much weaker in MAM (a, c, e) than in MNM (b, d, f). Bar=10 $\mu \mathrm{m}$. 
clarified that TLR-2-negative epithelial cells exist in the villous apices and this lack of TLR-2 might contribute to the bacterial adhesion to the villous apices in the rat small intestine [19]. From these findings, low TLRs-expression in the intestinal superficial epithelial cells might contribute to the preferential settlement of indigenous bacteria in MAM of the rat ascending colon.

In general, intestinal epithelial cells are generated in the intestinal crypts and exfoliate in the villous apices of the small intestine and in the intestinal superficial epithelium of the large intestine $[13,29,30]$. In the rat ascending colon, the proliferating area of epithelial cells is the middle portions of the intestinal crypts. Changes of epithelial cell proliferation in response to bacteria are investigated using germ-free animals. That is, the proliferation of epithelial cells and the number of epithelial cells in the intestinal crypts are fewer in the colons of germ-free rats than in conventional rats [2]. In the present study, $\mathrm{PCNA}^{+}$epithelial cells were more frequently found in the intestinal crypts with indigenous bacteria than in those without indigenous bacteria in MAM. Furthermore, $\mathrm{PCNA}^{+}$epithelial cells were located from the middle to apical portions of the intestinal crypts without indigenous bacteria in MAM, as in the previous reports [23, $31,36]$, but in the whole portions of the intestinal crypts with indigenous bacteria in MAM. Rapid migration and turnover of epithelial cells by the increase of epithelial proliferation is one of the host defense in the intestine [16, 26]. From these findings, the increase of proliferating epithelial cells and the expansion of proliferating area of epithelial cells are probably induced by the invasion of indigenous bacteria into the intestinal crypts of MAM, as one of the host defense in the rat ascending colon.

A large number of goblet cells are contained in the intestinal crypts of the large intestine [29]. The mucus layer formed by secretions of the goblet cells functions as a physical barrier against the bacteria $[18,21]$. Administration of normal rat microflora or LPS into germ-free rats induces an increase in both the number of goblet cells per intestinal crypt and the size of these cells and shifts the mucin property in goblet cells from acidic to neutral $[9,10]$. In the present study, $\mathrm{PCNA}^{+}$goblet cells were more abundant in the intestinal crypts with indigenous bacteria than in those without indigenous bacteria in MAM, although the total number of goblet cells was stable regardless of the existence of indigenous bacteria in the intestinal crypts of MAM. From these findings, the renewal of goblet cells is probably accelerated by the invasion of indigenous bacteria into the intestinal crypts of MAM, and the acceleration of mucus secretion associated with the accelerated renewal of goblet cells might exclude the hyper-proliferated indigenous bacteria in the intestinal crypts of the rat ascending colon.

In general, epithelial cell division is an event specific to stem cells and transit-amplifying cells in the intestinal crypts, and transit-amplifying cells terminally differentiate into absorptive cells or goblet cells [8]. The PCNA-immunopositive reactions detected in the goblet cells in the present study indicate the possibility that differentiated cells, such as goblet cells, could exert proliferative ability under special conditions, such as the proliferation of indigenous bacteria.

ACKNOWLEDGMENT. This work was financially supported in part by a Grant-in-Aid for Scientific Research (nos. 23580403 and 24-2965) from the Japan Society for the Promotion of Science.

\section{REFERENCES}

1. Akira, S., Uematsu, S. and Takeuchi, O. 2006. Pathogen recognition and innate immunity. Cell 124: 783-801. [Medline] [CrossRef]

2. Alam, M., Midtvedt, T. and Uribe, A. 1994. Differential cell kinetics in the ileum and colon of germfree rats. Scand. J. Gastroenterol. 29: 445-451. [Medline] [CrossRef]

3. Barthel, L. K. and Raymond, P. A. 1990. Improved method for obtaining 3- $\mu \mathrm{m}$ cryosections for immunocytochemistry. $J$. Histochem. Cytochem. 38: 1383-1388. [Medline] [CrossRef]

4. Batt, R. M., Rutgers, H. C. and Sancak, A. A. 1996. Enteric bacteria: friend or foe? J. Small Anim. Pract. 37: 261-267. [Medline] [CrossRef]

5. Cario, E., Rosenberg, I. M., Brandwein, S. L., Beck, P. L., Reinecker, H.C. and Podolsky, D. K. 2000. Lipopolysaccharide activates distinct signaling pathways in intestinal epithelial cell lines expressing Toll-like receptors. J. Immunol. 164: 966-972. [Medline]

6. Cario, E., Brown, D., McKee, M., Lynch-Devaney, K., Gerken, G. and Podolsky, D. K. 2002. Commensal-associated molecular patterns induce selective Toll-like receptor-trafficking from apical membrane to cytoplasmic compartments in polarized intestinal epithelium. Am. J. Pathol. 160: 165-173. [Medline] [CrossRef]

7. Cole, A. M. and Ganz, T. 2005. Defensins and other antimicrobial peptides: innate defense of mucosal surfaces. pp. 17-34. In: Colonization of Mucosal Surfaces, 2nd ed. (James, P. N. et al. eds.), ASM Press, Washington, D. C.

8. Crosnier, C., Stamataki, D. and Lewis, J. 2006. Organizing cell renewal in the intestine: stem cells, signals and combinatorial control. Nat. Rev. Genet. 7: 349-359. [Medline] [CrossRef]

9. Enss, M.L., Grosse-Siestrup, H., Schmidt-Wittig, U. and Gärtner, K. 1992. Changes in colonic mucins of germfree rats in response to the introduction of a "normal" rat microbial flora. $J$. Exp. Anim. Sci. 35: 110-119. [Medline]

10. Enss, M.L., Schmidt-Wittig, U., Müller, H., Mai, U. E. H., Coenen, M. and Hedrich, H. J. 1996. Response of germfree rat colonic mucous cells to peroral endotoxin application. Eur. J. Cell Biol. 71: 99-104. [Medline]

11. Fraune, S. and Bosch, T. C. G. 2010. Why bacteria matter in animal development and evolution. Bioessays 32: 571-580. [Medline] [CrossRef]

12. Gleeson, M., McFarlin, B. and Flynn, M. 2006. Exercise and Toll-like receptors. Exerc. Immunol. Rev. 12: 34-53. [Medline]

13. Han, H., Iwanaga, T. and Fujita, T. 1993. Species-differences in the process of apoptosis in epithelial cells of the small intestine: an ultrastructural and cytochemical study of luminal cell elements. Arch. Histol. Cytol. 56: 83-90. [Medline] [CrossRef]

14. Inamoto, T., Kawata, Y., Qi, W.M., Yamamoto, K., Warita, K., Kawano, J., Yokoyama, T., Hoshi, N. and Kitagawa, H. 2008. Ultrastructural study on the epithelial responses against attachment of indigenous bacteria to epithelial membranes in Peyer's patches of rat small intestine. J. Vet. Med. Sci. 70: 235-241. [Medline] [CrossRef]

15. Inamoto, T., Namba, M., Qi, W.M., Yamamoto, K., Yokoo, Y., 
Miyata, H., Kawano, J., Yokoyama, T., Hoshi, N. and Kitagawa, H. 2008. An immunohistochemical detection of actin and myosin in the indigenous bacteria-adhering sites of microvillous columnar epithelial cells in Peyer's patches and intestinal villi in the rat jejunoileum. J. Vet. Med. Sci. 70: 1153-1158. [Medline] [CrossRef]

16. Kim, M., Ashida, H., Ogawa, M., Yoshikawa, Y., Mimuro, H. and Sasakawa, C. 2010. Bacterial interactions with the host epithelium. Cell Host. Microbe 8: 20-35. [Medline] [CrossRef]

17. Laubitz, D., Zabielski, R., Woliński, J., Nieminuszczy, J. and Grzesiuk, E. 2003. Physiological and chemical characteristics of antibacterial activity of pancreatic juice. J. Physiol. Pharmacol. 54: 283-290. [Medline]

18. Laux, D. C., Cohen, P. S. and Conway, T. 2005. Role of the mucus layer in bacterial colonization of the intestine. pp. 199-212. In: Colonization of Mucosal Surfaces, 2nd ed. (James, P. N. et al. eds.), ASM Press, Washington, D. C.

19. Mantani, Y., Kamezaki, A., Udayanga, K. G. S., Takahara, E., Qi, W.M., Kawano, J., Yokoyama, T., Hoshi, N. and Kitagawa, H. 2011. Site differences of Toll-like receptor expression in the mucous epithelium of rat small intestine. Histol. Histopathol. 26: 1295-1303. [Medline]

20. Mantani, Y., Yokoo, Y., Kamezaki, A., Udayanga, K. G. S., Takahara, E., Takeuchi, T., Kawano, J., Yokoyama, T., Hoshi, N. and Kitagawa, H. 2012. Immunohistochemical detection of Tolllike receptor-2, -4 and -9 in exocrine glands associated with rat alimentary tract. J. Vet. Med. Sci. 74: 1429-1438. [Medline] [CrossRef]

21. McGuckin, M. A., Lindén, S. K., Sutton, P. and Florin, T. H. 2011. Mucin dynamics and enteric pathogens. Nat. Rev. Microbiol. 9: 265-278. [Medline] [CrossRef]

22. McKernan, D. P., Nolan, A., Brint, E. K., O'mahony, S. M., Hyland, N. P., Cryan, J. F. and Dinan, T. G. 2009. Toll-like receptor mRNA expression is selectively increased in the colonic mucosa of two animal models relevant to irritable bowel syndrome. PLoS One 4: e8226. [Medline] [CrossRef]

23. Messier, B. and Leblond, C. P. 1960. Cell proliferation and migration as revealed by radioautography after injection of thymidine- $\mathrm{H}^{3}$ into male rats and mice. Am. J. Anat. 106: $247-$ 285. [Medline] [CrossRef]

24. Netea, M. G., Van der Meer, J. W. M. and Kullberg, B. J. 2006. Recognition of pathogenic microorganisms by Toll-like receptors. Drugs Today 42: 99-105. [Medline]

25. Otte, J.M., Cario, E. and Podolsky, D. K. 2004. Mechanisms of cross hyporesponsiveness to Toll-like receptor bacterial ligands in intestinal epithelial cells. Gastroenterology 126: 1054-1070. [Medline] [CrossRef]

26. Qi, W.M., Yamamoto, K., Yokoo, Y., Miyata, H., Inamoto, T., Udayanga, K. G. S., Kawano, J., Yokoyama, T., Hoshi, N. and Kitagawa, H. 2009. Histoplanimetrical study on the relationship between the cell kinetics of villous columnar epithelial cells and the proliferation of indigenous bacteria in rat small intestine. $J$. Vet. Med. Sci 71: 463-470. [Medline] [CrossRef]

27. Qi, W.M., Yamamoto, K., Yokoo, Y., Miyata, H., Udayanga, K. G. S., Kawano, J., Yokoyama, T., Hoshi, N. and Kitagawa,
H. 2009. Histoplanimetrical study on the relationship between cellular kinetics of epithelial cells and proliferation of indigenous bacteria in the rat colon. J. Vet. Med. Sci. 71: 745-752. [Medline] [CrossRef]

28. Salminen, S., Isolauri, E. and Onnela, T. 1995. Gut flora in normal and disordered states. Chemotherapy 41: 5-15. [Medline] [CrossRef]

29. Shamsuddin, A. M., Phelps, P. C. and Trump, B. F. 1982. Human large intestinal epithelium: light microscopy, histochemistry, and ultrastructure. Hum. Pathol. 13: 790-803. [Medline] [CrossRef]

30. Shibahara, T., Sato, N., Waguri, S., Iwanaga, T., Nakahara, A., Fukutomi, H. and Uchiyama, Y. 1995. The fate of effete epithelial cells at the villus tips of the human small intestine. Arch. Histol. Cytol. 58: 205-219. [Medline] [CrossRef]

31. Sunter, J. P., Watson, A. J., Wright, N. A. and Appleton, D. R. 1979. Cell proliferation at different sites along the length of the rat colon. Virchows Arch. B Cell Path. 32: 75-87. [CrossRef]

32. Terán-Ventura, E., Roca, M., Martin, M. T., Abarca, M. L., Martinez, V. and Vergara, P. 2010. Characterization of housingrelated spontaneous variations of gut microbiota and expression of Toll-like receptors 2 and 4 in rats. Microb. Ecol. 60: 691-702. [Medline] [CrossRef]

33. Wang, Y., Devkota, S., Musch, M. W., Jabri, B., Nagler, C., Antonopoulos, D. A., Chervonsky, A. and Chang, E. B. 2010. Regional mucosa-associated microbiota determine physiological expression of TLR2 and TLR4 in murine colon. PLoS One 5: e13607. [Medline] [CrossRef]

34. Yamamoto, K., Qi, W.M., Yokoo, Y., Miyata, H., Udayanga, K. G. S., Kawano, J., Yokoyama, T., Hoshi, N. and Kitagawa, H. 2009. Histoplanimetrical study on the spatial relationship of distribution of indigenous bacteria with mucosal lymphatic follicles in alimentary tract of rat. J. Vet. Med. Sci. 71: 621-630. [Medline] [CrossRef]

35. Yamamoto, K., Qi, W.M., Yokoo, Y., Miyata, H., Udayanga, K. G. S., Kawano, J., Yokoyama, T., Hoshi, N. and Kitagawa, H. 2010. Lectin histochemical detection of special sugers on the mucosal surfaces of the rat alimentary tract. J. Vet. Med. Sci. 72: 1119-1127. [Medline] [CrossRef]

36. Yamada, K., Yoshitake, K., Sato, M. and Ahnen, D. J. 1992. Proliferating cell nuclear antigen expression in normal, preneoplastic, and neoplastic colonic epithelium of the rat. Gastroenterology 103: 160-167. [Medline]

37. Yokoo, Y., Miyata, H., Udayanga, K. G. S., Qi, W.M., Takahara, E., Yokoyama, T., Kawano, J., Hoshi, N. and Kitagawa, H. 2011. Immunohistochemical study on the secretory host defense system of bactericidal peptides in rat digestive organs. J. Vet. Med. Sci. 73: 217-225. [Medline] [CrossRef]

38. Yokoo, Y., Miyata, H., Udayanga, K. G. S., Qi, W.M., Takahara, E., Mantani, Y., Yokoyama, T., Kawano, J., Hoshi, N. and Kitagawa, H. 2011. Immunohistochemical and histoplanimetrical study on the spatial relationship between the settlement of indigenous bacteria and the secretion of bactericidal peptides in rat alimentary tract. J. Vet. Med. Sci. 73: 1043-1050. [Medline] [CrossRef] 